\title{
Gambaran Kejadian Nyeri Tenggorok dan Serak pada Pasien yang Menjalani Anestesi Umum Endotrakeal di RSUD Arifin Achmad Pekanbaru
}

\author{
Fitri Fahriyani ${ }^{1}$, Dino Irawan $^{2}$, Eka Bebasari $^{3^{*}}$
}

\begin{abstract}
Sore throat and hoarseness are common complications after endotracheal intubation. The incidence of sore throat and hoarseness after endotracheal intubation varies from 14 to $75 \%$. Although regarded as minor complications, sore throat and hoarseness contribute to postoperative morbidity and patient dissatisfaction. The aim of this study were to determine the incidence of sore throat and hoarseness after endotracheal general anesthesia and to describe associated risk factors at Arifin Achmad Public Hospital. This study used a descriptive cross sectional method. A total of 88 patients who underwent endotracheal general anesthesia were enrolled in this study. Data of the patient such as gender, age, duration of intubation and endotracheal tube size were collected from medical record and direct observation at the time of operation. All of the patients were interviewed within 24-36 hours after surgery to collect data such as smoking history, sore throat complaint and hoarseness complaint. The evaluation of sore throat degree was accomplished with a Capan's scale for sore throat and hoarseness degree was accomplished with a Stout's scale for hoarseness. The result showed that 18 patients $(20.4 \%)$ experienced sore throat and 34 patients $(38.6 \%)$ experienced hoarseness after surgery.
\end{abstract}

Keywords: sore throat, hoarseness, general endotracheal anesthesia

Pengelolaan jalan napas pasien dalam anestesi dapat dilakukan dengan berbagai cara antara lain dengan manuver tripel jalan napas (triple airway maneuver) atau dengan pemasangan alat seperti alat jalan napas faring (pharyngeal airway), sungkup muka (face mask), sungkup laring (laryngeal mask) dan pipa endotrakeal (endotracheal tube) atau dikenal sebagai intubasi. Di antara berbagai pilihan tersebut, intubasi adalah teknik yang lebih sering digunakan karena lebih cepat, akurat, sederhana dan aman dimana semua sasaran dari pengelolaan jalan napas dapat dicapai yaitu mempertahankan patensi jalan napas, mempermudah oksigenisasi dan mencegah aspirasi. Meskipun memiliki berbagai

\footnotetext{
1 Mahasiswa FK UR

2 Department of Anesthesia and Intensive Care, Arifin Achmad Public Hospital, Faculty of medicine, University of Riau

3* Coresponding Author: Department of Physiology, Faculty of medicine, University of Riau
}

kelebihan bukan berarti intubasi bebas dari komplikasi. ${ }^{1-6}$

Nyeri tenggorok dan serak adalah komplikasi intubasi yang paling sering dirasakan pasien setelah pulih dari anestesi. Insidensi nyeri tenggorok dan serak berkisar antara 14-75\%. McHardy et al menemukan, dari 1325 pasien yang diintubasi, 50\% pasien (663 orang) mengeluhkan timbulnya serak dan $14,4 \%$ pasien (191 orang) mengeluhkan timbulnya nyeri tenggorok. Biro et al menemukan, dari 809 pasien yang diintubasi, $40 \%$ pasien $(323$ orang) mengeluhkan timbulnya nyeri tenggorok. Yamanaka et al menemukan, dari 3093 pasien yang diintubasi, $49 \%$ pasien (1515 orang) mengeluhkan timbulnya serak. Satriyanto yang meneliti efektivitas ketamin kumur untuk mengurangi nyeri tenggorok pada pasien yang menjalani anestesi umum endotrakeal di RSUP Dr. Hasan Sadikin menemukan $4 \%$ pasien pada kelompok ketamin dan $24 \%$ pasien 
pada kelompok $\mathrm{NaCl} 0,9 \%$ mengeluhkan timbulnya nyeri tenggorok setelah pulih dari anestesi. ${ }^{6-9}$

Faktor risiko yang berperan dalam timbulnya keluhan nyeri tenggorok dan serak dapat dibagi menjadi faktor demografi dan faktor teknis. Faktor demografi antara lain jenis kelamin, usia dan riwayat merokok sedangkan faktor teknis antara lain lama terintubasi, ukuran pipa endotrakeal, tipe, tekanan dan medium yang digunakan untuk mengembangkan cuff dan adanya noda darah pada pipa endotrakeal saat ekstubasi. ${ }^{2-19}$

Nyeri tenggorok dan serak pada pasien yang menjalani anestesi umum endotrakeal umumnya tidak berakibat fatal tetapi hal ini dapat menyebabkan gangguan yang cukup berarti bagi pasien, menambah lama dan biaya rawatan pasien di rumah sakit dan meninggalkan kesan buruk terhadap operasi. Hal ini berakibat pada timbulnya ketidakpuasan pasien dan terkadang berujung pada claim terhadap rumah sakit., ${ }^{5,1320-22}$

Tingginya insidensi keluhan nyeri tenggorok dan serak pada pasien yang menjalani anestesi umum endotrakeal berdasarkan literatur dan cukup besarnya dampak yang ditimbulkan membangkitkan minat peneliti untuk meneliti mengenai topik ini. Mengingat belum adanya penelitian mengenai hal ini di RSUD Arifin Achmad Pekanbaru, maka peneliti tertarik untuk mengetahui bagaimana gambaran kejadian nyeri tenggorok dan serak pada pasien yang menjalani anestesi umum endotrakeal di RSUD Arifin Achmad Pekanbaru.

\section{METODE}

Penelitian ini merupakan penelitian deskriptif dengan desain penelitian studi cross sectional. Populasi penelitian ini adalah pasien yang menjalani anestesi umum endotrakeal di RSUD Arifin Achmad Pekanbaru pada Bulan Mei - Oktober 2011. Pengambilan sampel dilakukan dengan cara consecutive sampling dengan besar sampel minimal adalah 88 pasien. Variabel yang diteliti dalam penelitian ini antara lain jenis kelamin, usia, riwayat merokok, lama terintubasi, ukuran pipa endotrakeal, keluhan nyeri tenggorok dan keluhan serak.

Tindakan intubasi dilakukan sesuai dengan prosedur standar. Di ruang operasi akan dilakukan pengambilan data yang berkaitan dengan operasi dan intubasi yaitu nama, jenis kelamin, usia, tanggal dan jam operasi, jenis operasi, lama operasi, status fisik ASA, ukuran pipa endotrakeal, banyaknya percobaan intubasi dan lama terintubasi.

Pasien yang telah selesai menjalani operasi kemudian dipindahkan ke ruang pulih sadar sambil terus dilakukan pemantauan terhadap vital sign selanjutnya pasien akan dipindahkan ke ruang rawat inap. Dalam 24-36 jam pascaoperasi, peneliti akan mewawancarai pasien untuk mendapatkan data mengenai riwayat merokok, keluhan pada saluran pernapasan sebelum operasi, terapi steroid atau NSAID pada pasien dan untuk mengevaluasi keluhan nyeri tenggorok dan serak. Wawancara terhadap pasien ini hanya dilakukan satu kali.

Data yang diperoleh dikelompokkan berdasarkan variabel penelitian dan diolah secara manual dan komputerisasi kemudian disajikan dalam bentuk tabel distribusi frekuensi dan grafik untuk digunakan dalam mengambil kesimpulan.

\section{HASIL}

\section{Gambaran umum subjek penelitian}

Populasi dalam penelitian ini adalah pasien yang menjalani anestesi umum endotrakeal di RSUD Arifin Achmad pada bulan Mei - Oktober 2011. Didapatkan sampel sebanyak 88 pasien. Gambaran umum subjek penelitian dapat dilihat pada tabel 1 . 
Tabel 1. Karakteristik subjek penelitian

\begin{tabular}{ccc}
\hline Variabel & Frekuensi & Per sentase (\%) \\
Jenis kel amin & & \\
Pria & 28 & 31.8 \\
Wanita & 60 & 68.2 \\
Usia (tahun) & & \\
$18-30$ & 36 & 40.9 \\
\hline $31-40$ & 25 & 28.4 \\
$41-50$ & 17 & 19.3 \\
$51-60$ & 5 & 5.7 \\
$>60$ & 5 & 5.7 \\
Riwayat merokok & 15 & \\
Perokok & 73 & 17.0 \\
Bukan perokok & & 83.0 \\
Lama terintubasi (menit) & 34 & 38.6 \\
$<60$ & 54 & 61.4 \\
$\geq 60$ & & \\
Ukuran pipa endotrakeal & 27 & 30.7 \\
6.5 & 51 & 58.0 \\
7 & 10 & 11.3 \\
7.5 & &
\end{tabular}

\section{Gambaran derajat keluhan nyeri tenggorok subjek penelitian}

Keluhan nyeri tenggorok dievaluasi dengan menggunakan Capan's scale for sore throat. Nyeri tenggorok dibagi ke dalam 4 skor, skor 0 apabila pasien tidak mengeluhkan nyeri tenggorok, skor 1 apabila pasien mengeluhkan nyeri tenggorok ringan, skor 2 apabila pasien mengeluhkan nyeri tenggorok sedang dan skor 3 apabila pasien mengeluhkan nyeri tenggorok berat. ${ }^{23}$ Gambaran derajat keluhan nyeri tenggorok subjek penelitian dapat dilihat pada grafik 1 .

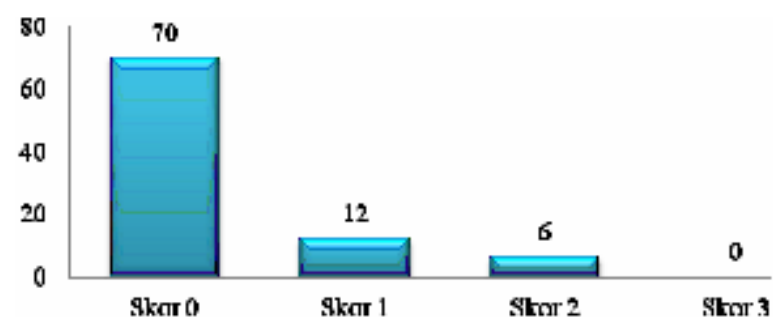

Grafik 1. Distribusi frekuensi subjek penelitian berdasarkan keluhan nyeri tenggorok
Berdasarkan grafik 1 dapat dilihat bahwa 70 pasien $(79.5 \%)$ tidak mengeluhkan timbulnya nyeri tenggorok pascaintubasi (skor 0) sedangkan 18 pasien $(20.4 \%)$ mengeluhkan timbulnya nyeri tenggorok pascaintubasi. Diantara pasien yang mengeluhkan nyeri tenggorok pascaintubasi, 12 pasien (13.6\%) mengeluhkan nyeri tenggorok ringan (skor 1) dan 6 pasien (6.8\%) mengeluhkan nyeri tenggorok sedang (skor 2). Tidak ada pasien yang mengeluhkan nyeri tenggorok berat (skor 3).

Gambaran derajat keluhan nyeri tenggorok subjek penelitian berdasarkanjenis kelamin, usia, riwayat merokok, lama terintubasi dan ukuran pipa endotrakeal

Gambaran derajat keluhan nyeri tenggorok subjek penelitian berdasarkan jenis kelamin, usia, riwayat merokok, lama terintubasi dan ukuran pipa endotrakeal dapat dilihat pada tabel 2. 
Tabel 2. Distribusi frekuensi derajat keluhan nyeri tenggorok subjek penelitian berdasarkan jenis kelamin, usia, riwayat merokok, lama terintubasi dan ukuran pipa endotrakeal

\begin{tabular}{|c|c|c|c|c|c|c|c|}
\hline \multirow{2}{*}{\multicolumn{3}{|c|}{ Faktor risiko }} & \multicolumn{4}{|c|}{ Skor nyeri tenggorok } & \multirow{2}{*}{ TOTAL } \\
\hline & & & Skor 0 & Skor 1 & Skor 2 & Skor 3 & \\
\hline \multirow{4}{*}{$\begin{array}{c}\text { Jenis } \\
\text { kelamin }\end{array}$} & \multirow{2}{*}{ Pria } & $\mathrm{n}$ & 22 & 3 & 3 & 0 & 28 \\
\hline & & $\%$ & 78.6 & 10.7 & 10.7 & 0 & 100 \\
\hline & \multirow{2}{*}{ Wanita } & $\mathrm{n}$ & 48 & 9 & 3 & 0 & 60 \\
\hline & & $\%$ & 80.0 & 15.0 & 5.0 & 0 & 100 \\
\hline \multirow{10}{*}{$\begin{array}{c}\text { Usia } \\
\text { (tahun) }\end{array}$} & \multirow{2}{*}{$18-30$} & $\mathrm{n}$ & 32 & 4 & 0 & 0 & 36 \\
\hline & & $\%$ & 88.9 & 11.1 & 0 & 0 & 100 \\
\hline & \multirow{2}{*}{$31-40$} & $\mathrm{n}$ & 21 & 2 & 2 & 0 & 25 \\
\hline & & $\%$ & 84.0 & 8.0 & 8.0 & 0 & 100 \\
\hline & \multirow{2}{*}{$41-50$} & $\mathrm{n}$ & 14 & 3 & 0 & 0 & 17 \\
\hline & & $\%$ & 82.4 & 17.6 & 0 & 0 & 100 \\
\hline & \multirow{2}{*}{$51-60$} & $\mathrm{n}$ & 2 & 2 & 1 & 0 & 5 \\
\hline & & $\%$ & 40.0 & 40.0 & 20.0 & 0 & 100 \\
\hline & \multirow{2}{*}{$>60$} & $\mathrm{n}$ & 1 & 1 & 3 & 0 & 5 \\
\hline & & $\%$ & 20.0 & 20.0 & 60.0 & 0 & 100 \\
\hline \multirow{4}{*}{$\begin{array}{l}\text { Riwayat } \\
\text { merokok }\end{array}$} & \multirow{2}{*}{ Perokok } & $\mathrm{n}$ & 8 & 4 & 3 & 0 & 15 \\
\hline & & $\%$ & 53.3 & 26.7 & 20.0 & 0 & 100 \\
\hline & \multirow{2}{*}{$\begin{array}{c}\text { Bukan } \\
\text { perokok }\end{array}$} & $\mathrm{n}$ & 62 & 8 & 3 & 0 & 73 \\
\hline & & $\%$ & 84.9 & 11.0 & 4.1 & 0 & 100 \\
\hline \multirow{4}{*}{$\begin{array}{c}\text { Lama } \\
\text { terintubasi } \\
\text { (menit) }\end{array}$} & \multirow{2}{*}{$<60$} & $\mathrm{n}$ & 28 & 5 & 1 & 0 & 34 \\
\hline & & $\%$ & 82.4 & 14.7 & 2.9 & 0 & 100 \\
\hline & \multirow{2}{*}{$\geq 60$} & $\mathrm{n}$ & 42 & 7 & 5 & 0 & 54 \\
\hline & & $\%$ & 77.8 & 13.0 & 9.2 & 0 & 100 \\
\hline \multirow{6}{*}{$\begin{array}{c}\text { Ukuran } \\
\text { pipa } \\
\text { endotrakeal }\end{array}$} & \multirow{2}{*}{6.5} & $\mathrm{n}$ & 25 & 0 & 2 & 0 & 27 \\
\hline & & $\%$ & 92.6 & 0 & 7.4 & 0 & 100 \\
\hline & \multirow{2}{*}{7} & $\mathrm{n}$ & 39 & 10 & 2 & 0 & 51 \\
\hline & & $\%$ & 76.5 & 19.6 & 3.9 & 0 & 100 \\
\hline & \multirow{2}{*}{7.5} & $\mathrm{n}$ & 6 & 2 & 2 & 0 & 10 \\
\hline & & $\%$ & 60.0 & 20.0 & 20.0 & 0 & 100 \\
\hline
\end{tabular}

\section{Gambaran derajat keluhan serak subjek penelitian}

Keluhan serak pada penelitian ini dievaluasi dengan menggunakan Stout's scale for hoarseness. Keluhan serak dibagi ke dalam 4 skor, skor 0 apabila pasien tidak mengeluhkan serak, skor 1 apabila pasien mengeluhkan serak ringan, skor 2 apabila pasien mengeluhkan serak sedang dan skor 3 apabila pasien mengeluhkan serak berat. ${ }^{24}$ Gambaran derajat keluhan serak subjek penelitian dapat dilihat pada grafik 2 .

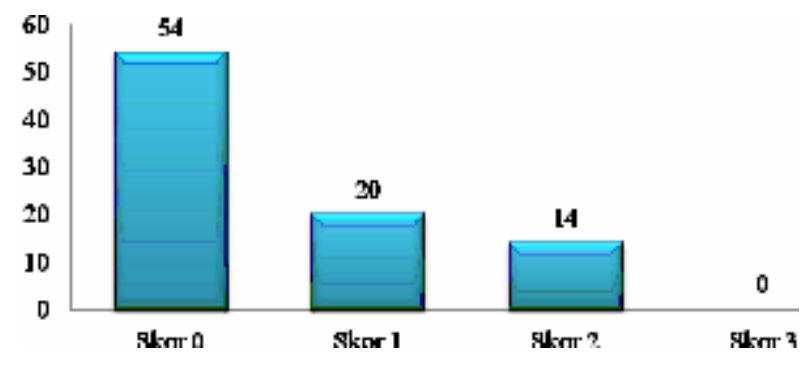

Grafik 2. Distribusi frekuensi subjek penelitian berdasarkan keluhan serak 
Berdasarkan grafik 2 dapat dilihat bahwa 54 pasien $(61.4 \%)$ tidak mengeluhkan timbulnya serak pascaintubasi (skor 0) sedangkan 34 pasien (38.6\%) mengeluhkan timbulnya serak pascaintubasi. Diantara pasien yang mengeluhkan timbulnya serak, 20 pasien $(22.7 \%)$ mengeluhkan serak ringan (skor 1) dan 14 pasien (15.9\%) mengeluhkan serak sedang (skor 2). Tidak ada pasien yang mengeluhkan serak berat (skor 3).
Gambaran derajat keluhan serak subjek penelitian berdasarkan jenis kelamin, usia, riwayat merokok, lama terintubasi dan ukuran pipa endotrakeal

Gambaran derajat keluhan serak subjek penelitian berdasarkan jenis kelamin, usia, riwayat merokok, lama terintubasi dan ukuran pipa endotrakeal dapat dilihat pada tabel 3.

Tabel 3. Distribusi frekuensi derajat keluhan serak subjek penelitian berdasarkan jenis kelamin, usia, riwayat merokok, lama terintubasi dan ukuran pipa endotrakeal

\begin{tabular}{|c|c|c|c|c|c|c|c|}
\hline \multirow{2}{*}{\multicolumn{3}{|c|}{ Faktor risiko }} & \multicolumn{4}{|c|}{ Skor serak } & \multirow{2}{*}{ TOTAL } \\
\hline & & & Skor 0 & Skor 1 & Skor 2 & Skor 3 & \\
\hline \multirow{4}{*}{$\begin{array}{c}\text { Jenis } \\
\text { kelamin }\end{array}$} & \multirow{2}{*}{ Pria } & $\mathrm{n}$ & 19 & 5 & 4 & 0 & 28 \\
\hline & & $\%$ & 67.8 & 17.9 & 14.3 & 0 & 100 \\
\hline & \multirow{2}{*}{ Wanita } & $\mathrm{n}$ & 35 & 15 & 10 & 0 & 60 \\
\hline & & $\%$ & 58.3 & 25.0 & 16.7 & 0 & 100 \\
\hline \multirow{10}{*}{$\begin{array}{c}\text { Usia } \\
\text { (tahun) }\end{array}$} & \multirow{2}{*}{$18-30$} & $\mathrm{n}$ & 24 & 7 & 5 & 0 & 36 \\
\hline & & $\%$ & 66.7 & 19.4 & 13.9 & 0 & 100 \\
\hline & \multirow{2}{*}{$31-40$} & $\mathrm{n}$ & 13 & 9 & 3 & 0 & 25 \\
\hline & & $\%$ & 52.0 & 36.0 & 12.0 & 0 & 100 \\
\hline & \multirow{2}{*}{$41-50$} & $\mathrm{n}$ & 11 & 2 & 4 & 0 & 17 \\
\hline & & $\%$ & 64.7 & 11.8 & 23.5 & 0 & 100 \\
\hline & \multirow{2}{*}{$51-60$} & $\mathrm{n}$ & 2 & 2 & 1 & 0 & 5 \\
\hline & & $\%$ & 40.0 & 40.0 & 20.0 & 0 & 100 \\
\hline & \multirow{2}{*}{$>60$} & $\mathrm{n}$ & 4 & 0 & 1 & 0 & 5 \\
\hline & & $\%$ & 80.0 & 0 & 20.0 & 0 & 100 \\
\hline \multirow{4}{*}{$\begin{array}{l}\text { Riwayat } \\
\text { merokok }\end{array}$} & \multirow{2}{*}{ Perokok } & $\mathrm{n}$ & 8 & 4 & 3 & 0 & 15 \\
\hline & & $\%$ & 53.3 & 26.7 & 20.0 & 0 & 100 \\
\hline & \multirow{2}{*}{$\begin{array}{l}\text { Bukan } \\
\text { perokok }\end{array}$} & $\mathrm{n}$ & 46 & 16 & 11 & 0 & 73 \\
\hline & & $\%$ & 63.0 & 21.9 & 15.1 & 0 & 100 \\
\hline \multirow{4}{*}{$\begin{array}{c}\text { Lama } \\
\text { terintubasi } \\
\text { (menit) }\end{array}$} & \multirow{2}{*}{$<60$} & $\mathrm{n}$ & 21 & 8 & 5 & 0 & 34 \\
\hline & & $\%$ & 61.8 & 23.5 & 14.7 & 0 & 100 \\
\hline & \multirow{2}{*}{$\geq 60$} & $\mathrm{n}$ & 33 & 12 & 9 & 0 & 54 \\
\hline & & $\%$ & 61.1 & 22.2 & 16.7 & 0 & 100 \\
\hline \multirow{6}{*}{$\begin{array}{c}\text { Ukuran } \\
\text { pipa } \\
\text { endotrakeal }\end{array}$} & \multirow{2}{*}{6.5} & $\mathrm{n}$ & 17 & 4 & 6 & 0 & 27 \\
\hline & & $\%$ & 63.0 & 14.8 & 22.2 & 0 & 100 \\
\hline & \multirow{2}{*}{7} & $\mathrm{n}$ & 29 & 15 & 7 & 0 & 51 \\
\hline & & $\%$ & 56.9 & 29.4 & 13.7 & 0 & 100 \\
\hline & \multirow{2}{*}{7.5} & $\mathrm{n}$ & 8 & 1 & 1 & 0 & 10 \\
\hline & & $\%$ & 80.0 & 10.0 & 10.0 & 0 & 100 \\
\hline
\end{tabular}




\section{PEMBAHASAN}

\section{Gambaran derajat keluhan nyeri tenggorok subjek penelitian}

Persentase kejadian nyeri tenggorok pada penelitian ini adalah 20.4\%. Persentase kejadian nyeri tenggorok pada penelitian ini lebih kecil dibandingkan hasil penelitian Satriyanto (24.0\%), Park et al (27.3\%), Ahmed et al (26.0\%) dan Biro et al (40.0\%) tetapi lebih besar dibandingkan dengan penelitian McHardy et al (14.4\%). Variasi tersebut dapat terjadi karena insidensi nyeri tenggorok pascaintubasi berbeda untuk tiap ras..$^{67,9,21,25}$

Tidak adanya pasien yang mengeluhkan nyeri tenggorok berat dapat disebabkan karena pada umumnya pasien lebih mengeluhkan nyeri di sekitar area operasi sehingga nyeri di tenggorok yang mereka rasakan tidak terlalu diperhatikan. ${ }^{7,9,16}$

\section{Gambaran derajat keluhan nyeri tenggorok subjek penelitian berdasarkan jenis kelamin}

Pada tabel 2 dapat dilihat bahwa keluhan nyeri tenggorok lebih banyak terjadi pada pria. Dari 28 pasien pria, $21.4 \%$ (6 orang) mengeluhkan nyeri tenggorok pascaintubasi sedangkan pada pasien wanita, sebanyak $20.0 \%$ (12 orang) dari 60 pasien wanita mengeluhkan nyeri tenggorok.

Berdasarkan literatur, wanita lebih berisiko mengalami nyeri tenggorok karena diameter jalan napas yang lebih kecil dan membran mukosa saluran napas yang lebih tipis. Pada penelitian Ahmed et $a l$, nyeri tenggorok pascaintubasi lebih banyak ditemukan pada pasien wanita yaitu $27.1 \%$ sedangkan pasien pria yang mengeluhkan nyeri tenggorok pascaintubasi sebanyak $19.1 \%$. Dari penelitian McHardy et al juga didapatkan insidensi nyeri tenggorok lebih tinggi pada pasien wanita. Tetapi dari penelitian Kadri et al, pasien pria lebih banyak mengeluhkan nyeri tenggorok pascaintubasi dimana $92.9 \%$ pasien pria mengeluhkan nyeri tenggorok sedangkan pasien wanita yang mengeluhkan nyeri tenggorok hanya $78.6 \%$. Berdasarkan penelitian Edomwonyi et al, meskipun nyeri tenggorok pascaintubasi lebih sering dikeluhkan oleh pasien wanita, setelah melalui analisis statistik, tidak ada perbedaan bermakna untuk insidensi nyeri tenggorok antara kedua jenis kelamin tersebut. ${ }^{5,7,14-16,25}$

\section{Gambaran derajat keluhan nyeri tenggorok subjek penelitian berdasarkan usia}

Hasil penelitian tabel 2 menunjukkan bahwa keluhan nyeri tenggorok lebih banyak ditemukan pada pasien yang berusia di atas 60 tahun. Hasil ini sesuai dengan hasil penelitian Ahmed et al dimana persentase kejadian nyeri tenggorok pascaintubasi terbanyak adalah pada kelompok usia di atas 60 tahun. Menurut penelitian tersebut, dari 29 pasien yang berusia di atas 60 tahun, 37.9\% (11 orang) mengeluhkan nyeri tenggorok pascaintubasi. Berdasarkan literatur, pasien berusia di atas 60 tahun lebih berisiko mengalami nyeri tenggorok karena membran mukosa saluran napas yang lebih tipis sehingga lebih rentan terhadap trauma. ${ }^{5,14,25}$

\section{Gambaran derajat keluhan nyeri tenggorok subjek penelitian berdasarkan riwayat merokok}

Keluhan nyeri tenggorok lebih banyak ditemukan pada pasien yang merupakan perokok. Hal ini sesuai dengan penelitian Elhakim et al dimana $26.0 \%$ pasien yang merupakan perokok mengeluhkan nyeri tenggorok pascaintubasi sedangkan persentase kejadian nyeri tenggorok pascaintubasi pada pasien yang bukan perokok adalah 23.0\%. Berdasarkan literatur, pasien perokok lebih berisiko mengalami nyeri tenggorok pascaintubasi karena kandungan zat iritan dalam rokok yang dapat memicu keringnya mukosa trakea dan penurunan integritas sel saluran pernapasan sehingga lebih rentan terhadap trauma. ${ }^{6,36}$

\section{Gambaran derajat keluhan nyeri tenggorok subjek penelitian berdasarkan lama terintubasi}

Pada tabel 2 dapat dilihat bahwa nyeri tenggorok lebih banyak dikeluhkan oleh pasien dengan lama terintubasi e" 60 menit. Hal ini sesuai dengan hasil penelitian Elhakim et al dimana pasien dengan lama terintubasi e" 60 menit yang mengeluhkan nyeri tenggorok pada penelitian tersebut sebanyak $29.0 \%$ sedangkan kejadian nyeri tenggorok pada pasien dengan lama terintubasi $<60$ menit adalah $22.0 \%$. Pasien dengan lama terintubasi e" 60 menit lebih cenderung mengalami nyeri tenggorok karena semakin lama kontak antara pipa endotrakeal dengan mukosa saluran napas, semakin besar kemungkinan terjadinya trauma pada mukosa 
saluran napas dan gangguan perfusi jaringan. Gangguan perfusi jaringan dapat terjadi karena adanya penekanan cuff pada mukosa trakea. Tekanan cuff yang melebihi tekanan kapiler trakea (27-40 $\mathrm{cmH}_{2} \mathrm{O}$ ) selama minimal 15 menit akan menimbulkan iskemia jaringan. ${ }^{18,26}$

\section{Gambaran derajat keluhan nyeri tenggorok subjek penelitian berdasarkan ukuran pipa endotrakeal}

Berdasarkan tabel 2 pasien yang diintubasi dengan pipa endotrakeal ukuran 7.5 lebih banyak mengeluhkan nyeri tenggorok pascaintubasi. Hasil ini sesuai dengan penelitian Kadri et al yang menemukan bahwa pasien yang diintubasi dengan pipa endotrakeal ukuran 7.5 lebih banyak mengeluhkan nyeri tenggorok pascaintubasi. Dari penelitian tersebut, 35\% (49 orang) pasien yang diintubasi dengan pipa endotrakeal ukuran 7.5 mengeluhkan nyeri tenggorok pascaintubasi. Berdasarkan literatur, penggunaan pipa endotrakeal dengan ukuran yang lebih besar berpotensi untuk menimbulkan nyeri tenggorok terkait dengan semakin luasnya area kontak antara pipa endotrakeal dengan mukosa saluran napas. ${ }^{3,16}$

\section{Gambaran derajat keluhan serak subjek penelitian}

Hasil penelitian grafik 2 menunjukkan bahwa sebagian besar subjek penelitian tidak mengeluhkan timbulnya serak pascaintubasi. Persentase kejadian serak pascaintubasi pada penelitian ini adalah $38.6 \%$. Persentase serak pascaintubasi pada penelitian ini lebih besar dibandingkan dengan hasil yang didapat dari penelitian Ahmed et al tetapi lebih kecil dibandingkan dengan hasil penelitian Yamanaka et al dan Mencke et al..$^{8,13,25}$

Pada penelitian Ahmed et al, dari 312 pasien yang diintubasi, $29.0 \%$ (90 orang) pasien mengeluhkan timbulnya serak. Sedangkan pada penelitian Yamanaka et al, dari 3093 pasien yang diintubasi, $49.0 \%$ (1515 orang) pasien mengeluhkan timbulnya serak dan pada penelitian Mencke et al, dari 36 pasien yang diintubasi, $44.0 \%$ (16 orang) pasien mengeluhkan timbulnya serak. Adanya variasi dalam persentase kejadian serak tersebut mungkin disebabkan karena adanya perbedaan dalam waktu wawancara pada tiap-tiap penelitian. Ahmed et al melakukan wawancara setelah 24 jam pascaoperasi, Yamanaka et al melakukan wawancara sebanyak tiga kali yaitu pada hari pertama, kedua dan ketiga pascaoperasi dan Mencke et al melakukan wawancara sebanyak tiga kali yaitu pada hari pertama, ketiga dan ketujuh pascaoperasi. . $^{8,1325}$

Berdasarkan grafik 2 tersebut dapat dilihat bahwa tidak ada pasien yang mengeluhkan serak berat. Hasil ini sama dengan hasil yang didapat dari penelitian yang dilakukan oleh Salvalaggio et al. ${ }^{27}$

\section{Gambaran derajat keluhan serak subjek penelitian berdasarkan jenis kelamin}

Pada tabel 3 dapat dilihat bahwa keluhan serak lebih banyak terjadi pada pasien wanita. Hal ini sesuai dengan hasil penelitian Maktabi et al dimana berdasarkan penelitian tersebut, $60.7 \%$ pasien wanita yang diintubasi mengeluhkan serak pascaintubasi sedangkan pasien pria yang mengeluhkan serak pascaintubasi hanya $46.6 \%$. Meskipun dari penelitian tersebut didapatkan pasien wanita lebih banyak mengalami serak pascaintubasi, jenis kelamin bukan merupakan faktor risiko yang bermakna secara statistik terhadap insidensi keluhan serak pascaintubasi. ${ }^{28}$

\section{Gambaran derajat keluhan serak subjek penelitian berdasarkan usia}

Hasil penelitian (tabel 3) menunjukkan bahwa serak lebih banyak dikeluhkan oleh pasien dari kelompok usia 51-60 tahun. Hal ini sesuai dengan hasil penelitian Kikura et al dimana risiko terjadinya serak lebih tinggi pada pasien yang berusia e"50 tahun. Pada penelitian tersebut, pasien yang berusia e"50 tahun memiliki risiko 3 kali lebih tinggi untuk mengalami serak pascaintubasi. ${ }^{29}$

\section{Gambaran derajat keluhan serak subjek penelitian berdasarkan riwayat merokok}

Keluhan serak lebih banyak terjadi pada pasien yang merupakan perokok. Hal ini sesuai dengan penelitian Smith-Hammond et al dimana adanya kebiasaan merokok pada pasien merupakan faktor risiko yang bermakna secara statistik terhadap insidensi keluhan serak pascaintubasi. ${ }^{30}$ 


\section{Gambaran derajat keluhan serak subjek penelitian berdasarkan lama terintubasi}

Pada tabel 3 dapat dilihat bahwa keluhan serak lebih banyak ditemukan pada pasien dengan lama terintubasi e" 60 menit. Hal ini sesuai dengan penelitian Yamanaka et al. Berdasarkan penelitian tersebut lama terintubasi merupakan faktor risiko yang bermakna terhadap insidensi serak pascaintubasi. $^{8}$

\section{Gambaran derajat keluhan serak subjek penelitian berdasarkan ukuran pipa endotrakeal}

Berdasarkan tabel 3, pasien yang diintubasi dengan pipa endotrakeal ukuran 7 lebih banyak mengeluhkan serak pascaintubasi. Berdasarkan literatur, semakin besar ukuran pipa endotrakeal yang digunakan, semakin tinggi risiko terjadinya serak pascaintubasi. Pada penelitian Kadri et al, pasien yang diintubasi dengan pipa endotrakeal ukuran 7.5 lebih banyak mengeluhkan serak pascaintubasi namun dari penelitian Jaensson et al, ukuran pipa endotrakeal tidak bermakna secara statistik terhadap peningkatan insidensi serak pascaintubasi. ${ }^{16,31}$

\section{KETERBATASAN PENELITIAN}

Pada penelitian ini, evaluasi keluhan nyeri tenggorok dan serak hanya dilakukan satu kali, yaitu dalam 24-46 jam pascaoperasi. Agar evaluasi yang dilakukan maksimal, beberapa penelitian melakukan observasi sebanyak tiga kali. Selain itu, faktor risiko yang paling berpengaruh, yaitu tekanan cuff pipa trakea tidak diteliti.

\section{KESIMPULAN}

Berdasarkan hasil penelitian yang telah dilakukan dapat diambil kesimpulan:

1. Persentase pasien yang menjalani anestesi umum endotrakeal yang mengeluhkan nyeri tenggorok pascaintubasi adalah $20.4 \%$ dan persentase pasien yang mengeluhkan serak pascaintubasi adalah $38.6 \%$.

2. Berdasarkan jenis kelamin, nyeri tenggorok lebih banyak ditemukan pada pasien pria yaitu $21.4 \%$ sedangkan keluhan serak lebih banyak ditemukan pada pasien wanita yaitu $41.7 \%$.

3. Berdasarkan usia, nyeri tenggorok lebih banyak dikeluhkan oleh pasien yang berusia di atas 60 tahun yaitu $80.0 \%$ sedangkan serak lebih banyak dikeluhkan oleh pasien yang berusia $51-60$ tahun yaitu $60.0 \%$.

4. Berdasarkan riwayat merokok, keluhan nyeri tenggorok lebih banyak ditemukan pada pasien yang merupakan perokok yaitu $46.7 \%$. Keluhan serak juga lebih banyak ditemukan pada pasien yang merupakan perokok yaitu $46.7 \%$.

5. Berdasarkan lama terintubasi, nyeri tenggorok lebih banyak dikeluhkan oleh pasien dengan lama terintubasi e" 60 menit yaitu 22.2\%. Serak juga lebih banyak dikeluhkan oleh pasien dengan lama terintubasi e" 60 menit yaitu $38.9 \%$.

6. Berdasarkan ukuran pipa endotrakeal, keluhan nyeri tenggorok lebih banyak ditemukan pada pasien yang diintubasi dengan pipa endotrakeal ukuran 7.5 yaitu $40.0 \%$ sedangkan keluhan serak lebih banyak ditemukan pada pasien yang diintubasi dengan pipa endotrakeal ukuran 7 yaitu $43.1 \%$.

\section{UCAPAN TERIMA KASIH}

Ucapan terima kasih ini penulis sampaikan kepada seluruh pihak yang telah berpartisipasi dalam menyelesaikan penelitian ini.

\section{DAFTAR PUSTAKA}

1. Latief SA, Suryadi KA, Dachlan MR. Petunjuk Praktis Anestesiologi. Edisi kedua. Jakarta: Bagian Anestesiologi dan Terapi Intensif Fakultas Kedokteran Universitas Indonesia; 2009.

2. Finucane BT, Santora AH. Principle of Airway Management. $3^{\text {th }}$ ed. New York: Springer-Verlag Inc.; 2003.

3. Henderson J. Tracheal Intubation of the Adult Patient. In: Calder I, Pearce A, editors. Core Topic in Airway Management. New York: Cambridge University Press; 2005. p. 69-80. 
4. Davies NJH, Cashman JN, editors. Lee's Synopsis of Anaesthesia. 13 ${ }^{\text {th }}$ ed. Philadelphia: Butterworth Heinemann; 2005.

5. Divatia JV, Bhowmick K. Complications of Endotracheal Intubation and Other Airway Management Procedures. Indian J.Anaesth. 2005;49(4):308-318.

6. Biro P, Seifert B, Pasch T. Complaints of sore throat after tracheal intubation: a prospective evaluation. European Journal of Anaesthesiology. 2005;22:307-311.

7. McHardy FE, Chung F. Postoperative Sore Throat: Cause, Prevention And Treatment. Anaesthesia. 1999;54:444-453.

8. Yamanaka H, Hayashi Y, Watanabe Y, Uematu $\mathrm{H}$, Mashimo T. Prolonged hoarseness and arytenoid cartilage dislocation after tracheal intubation. British Journal of Anaesthesia. 2009;103(3):452-5.

9. Satriyanto MD. Efektivitas Ketamin Kumur untuk Mengurangi Sore Throat Pascaintubasi pada Pasien yang Menjalani Anestesi Umum Endotrakeal untuk Operasi Ginekologis [tesis]. Bandung: Universitas Padjadjaran; 2010.

10.Mencke T, Knoll H, Schreiber JU, Echternach M, Klein S, Noeldge-Schomburg G, et al. Rocuronium is Not Associated with More Vocal Cord Injuries than Succinylcholine After RapidSequence Induction: A Randomized, Prospective, Controlled Trial. Anesth Analg. 2006;102:9439.

11. Mencke T, Echternach M, Plinkert PK, Johann U, Afan N, Rensing H. et al. Does the Timing of Tracheal Intubation Based on Neuromuscular Monitoring Decrease Laryngeal Injury? A Randomized, Prospective, Controlled Trial. Anesth Analg. 2006;102:306-12.

12.Kazemi A, Amini A. The Effect Of Betamethasone Gel in Reducing Sore Throat, Cough, and Hoarseness After Laryngo-Tracheal Intubation. M.E.J. Anesth. 2007;19(1):197-204.

13.Mencke T, Echternach M, Kleinschmidt S, Lux P, Barth V, Plinkert PK, et al. Laryngeal Morbidity and Quality of Tracheal Intubation: A Randomized Controlled Trial. Anesthesiology. 2003;98:1049-56.
14.Asai T, Koga K, Vaughan RS. Respiratory Complication Associated with Tracheal Intubation and Extubation. British Journal of Anaesthesia. 1998;80:767-775.

15.Edomwonyi NP, Ekwere IT, Omo E, Rupasinghe A. Postoperative Throat Complications after Tracheal Intubation. Annals of African Medicine. 2006;5(1):28-32.

16.Kadri IA, Khanzada TK, Samad A, Memon W. Post-Thyroidectomy Sore Throat: A Common Problem. Pak J Med Sci. 2009; 25(3): 408-412.

17. Sengupta P, Sessler DI, Maglinger P, Wells S, Vogt A, Durrani J. Endotracheal Tube Cuff Pressure In Three Hospitals, And The Volume Required To Produce An Appropriate Cuff Pressure. BMC Anesthesiology. 2004;4:8.

18. Rokamp KZ, Secher NH, Møller AM, Nielsen HB. Tracheal Tube And Laryngeal Mask Cuff Pressure During Anaesthesia - Mandatory Monitoring Is In Need. BMC Anesthesiology. 2010;10:20.

19. Manissery JJ, Shenoy V, Ambareesha M. Endotracheal Tube Cuff Pressures During General Anaesthesia While Using Air Versus A 50\% Mixture Of Nitrous Oxide And Oxygen As Inflating Agents. Indian J. Anaesth. 2007;51(1): $24-27$.

20.Gwinnutt CL. Lecture Notes Clinical Anaesthesia. $2^{\text {nd }}$ ed. Blackwell Publishing Ltd.; 2004.

21.Park SY, Kim SH, Lee A, Cho SH, Chae WS, Jin HC, et al. Prophylactic Effect of Dexamethasone in Reducing Postoperative Sore Throat. Korean Society of Anesthesiologists. 2010;58:15-19.

22.Undang-Undang Republik Indonesia Nomor 44 Tahun 2009 Tentang Rumah Sakit. Diakses dari: http://www.litbang.depkes.go.id [diakses tanggal 14 Januari 2011]

23.Capan LM, Bruce DL, Patel KP, Turndof H. Succinylcholine-induced Postoperative Sore Throat. Anesthesiology. 1983;59:202-6.

24. Stout DM, Bishop MJ, Dwersteg JF, Cullen BF. Correlation of Endotracheal Tube Size with Sore Throat and Hoarseness Following General Anaesthesia. Anesthesiology. 1987;67:419-21. 
25.Ahmed A, Abbasi S, Ghafoor HB, Ishaq M. Postoperative Sore Throat After Elective Surgical Procedures. J Ayub Med Coll Abbottabad. 2007;19(2):12-4.

26.Elhakim M, Siam A, Rashed I, Hamdy MH. Topical Tenoxicam From Pharyngeal Pack Reduces Postoperative Sore Throat. Acta Anaesthesiologica Scandinavica. 2000;44:733736.

27. Salvalaggio MFO, Rehme R, Fernandez R, Vieira S, Nakashima P. A Comparative Study Between the Laryngoscope and Lighted Stylet in Tracheal Intubation. Rev Bras Anestesiol. 2010;60:138143.

28. Maktabi MA, Wachtel RE, Savage KJ, Brigham KC. Females are at Greater Risk for Postoperative Hoarseness than Males. Anesthesiology suppl. 2006;105:103-5.
29.Kikura M, Suzuki K, Itagaki T, Takada T, Sato S. Age and Comorbidity as Risk Factors for Vocal Cord Paralysis Associated with Tracheal Intubation. Br J Anaesth. 2007;98(4):524-30.

30.Smith-Hammond CA, Pietrobon R. Curtis DJ, Scharver CH, Turner DA. Prospective Analysis of Incidence and Risk Factor of Dysphagia in Spine Surgery Patients: Comparison of Anterior Cervical, Posterior Cervical and Lumbar Procedure. Spine. 2004; 29(13):1441-6.

31.Jaensson M, Olowsson LL, Nilsson U. Endotracheal Tube Size and Sore Throat Following Surgery: A Randomized-controlled Study. Acta Anaesthesiol Scand. 2010;54:147153. 